\title{
CAPAIAN STANDAR PROSES IMPLEMENTASI KURIKULUM 2013 (STUDI KASUS PADA SMA 1, SMA 2 dan SMA 5 SEBAGAI SEKOLAH PILOTING KOTA BALIKPAPAN)
}

\author{
Casmudi \\ FKIP UNIVERSITAS BALIKPAPAN \\ casmudibpn62@gmail.com
}

\begin{abstract}
This study aims to reveal: (1) process standard achievement (2) obstacles faced by schools (3) strategy to overcome obstacles in the implementation of Curriculum 2013. The method used in this research is qualitative method with observation approach, interview and document study. Data subject; Principals, Vice facility and Curriculum, subject teachers, students and parent representatives. Research result; (1) Principles of learning, (2) Learning Planning, (3) Lesson Plan, covering Introduction, core activities and closing (4) assessment of learning outcomes done with three domains, attitudes, knowledge, and skills of achievement are, (a) SMA N 5; 87.55 (b) SMA N 2; 88.88 and (c) SMA N 1; 94.44, (5) Supervision of learning outcomes is done in four steps; (a) Monitoring, this activity is carried out by the principal and supervisor of the supervisor in each school, (b) supervision of teachers in the class conducted by Subject supervisors, using the instrument, the results of class supervision prepared semester final report, the result of the average teacher is 7.8. Teachers with less than 70 supervision scores, follow-up step by giving specific guidance and priority supervision entry. Implications of implementation of process standards as piloting school drivers improve SKS program as a follow-up channel of optimization of learning process standards in channelling students' academic interests and talents accordingly with its characteristics.
\end{abstract}

Keywords : Standard Achievement, Pilot Project School

Penelitian ini bertujuan untuk mengungkap: (1) ketercapaian standar proses, (2) kendala dihadapi sekolah, (3) strategi mengatasi kendala implementasi Kurikulum 2013. Metode yang digunakan dalam penelitian adalah metode kualitatif dengan pendekatan observasi, wawancara dan studi dokumen. Subyek data; Kepala sekolah, Wakil Kurikulum dan Sarana, guru mata pelajaran, siswa dan wakil orangtua. Hasil penelitian; (1) Prinsip pembelajaran, (2) Perencanaan Pembelajaran, (3) Pelaksanaan Pembelajaran, meliputi Pendahuluan, kegiatan inti dan penutup, (4) penilaian hasil pembelajaran dilakukan dengan tiga ranah, sikap, pengetahuan, dan keterampilan hasil capaiannya adalah, (a) SMA Negeri 5; 87,55 (b) SMA Negeri 2; 88.88 dan (c) SMA Negeri 1; 94,44 (5) Pengawasan hasil pembelajaran dilakukan dengan empat langkah; (a) pemantauan, kegiatan ini dilakukan oleh kepala sekolah dan pengawas pembina di masing-masing sekolah, (b) supervisi guru di kelas dilakukan pengawas mata pelajaran, menggunakan instrumen, hasil supervisi kelas disusun laporan akhir semester, hasilnya rata-rata guru sebesar 7,8. Bagi guru nilai supervisi kurang 70, ditindaklanjuti bimbingan khusus dan masuk prioritas pengawasan berikutnya. Implikasi dari implementasi standard proses sebagai pendorong sekolah piloting meningkatkan program SKS sebagai tindaklanjut penyaluran optimalisasi standard proses pembelajaran dalam menyalurkan minat dan bakat akademik siswa sesuai dengan karakteristiknya.

Kata Kunci : Capaian Standar, Sekolah Piloting 


\section{PENDAHULUAN}

Kegiatan pembelajaran bermutu, menginspiratif, menyenangkan, pelayanan penuh perhatian dan kelembutan, menantang kecerdasan anak, dan jauh dari ketegangan, keterpaksaan, dan kemalasan merupakan gambaran aktivitas yang diharapkan para siswa. Suasana digambarkan di atas tidak lepas dari peran dan fungsi guru sebelum masuk memulai pembelajaran, saat pembelajaran berlangsung hingga mengawal dengan cermat perkembangan kognitif, afektif dan psikomotrik tiap siswa.

Bambang Sulistyo, (2013:36) Proses pembelajaran pada satuan pendidikan sesuai dengan kurikulum 2013, idealnya diselenggarakan secara interaktif, inspiratif, menyenangkan, menantang, memotivasi siswa, untuk berpartisipasi aktif, serta terdapat kesempatan untuk berprakarsa, kreatif, mandiri sesuai dengan bakat, minat dan susuai dengan perkembangan fisik dan psiokologis peserta didiknya.

Hoy dkk (2000) dalam Ungsi AO Maramai (2002:108) schools must show what the pupils know and $d o^{\prime}$ and will be hold accountable in those terms. Pembelajaran bermutu adalah pembelajaran yang berhasil guna dan berdaya guna. Berhasil guna berarti proses belajar dapat mencapai tujuan dan sasaran yang diharapkan (efektif), berdaya guna berarti proses belajar dapat mencapai sasaran yang diharapkan dengan biaya murah dan waktu yang relative singkat (efisien). Untuk membuat pembelajaran bermutu, diperlukan persiapan guru yang matang dan cermat.

Menurut Afriani Rika (2008) persiapan pembelajaran yang dilakukan guru terjadi kebingungan dalam menetapkan indikator/ tujuan pembelajaran, khususnya pembelajaran yang menghasilkan tingkatan berfikir tinggi (hight order thinking skils). Aspek penyusunan RPP semua guru Bahasa Indonesia sudah memenuhi standard sesuai dengan format yang disepakati dalam musyawarah guru mata pelajaran (MGMP) Bahasa Indonesia. Aspek perencanaan ini yang belum dapat memenuhi acuan pedoman standard proses yaitu, penyiapan media pembelajaran, bahan ajar buatan guru sekolah, dan soal yang tepat sesuai dengan kondisi sekolah.

Dalam pengamatan penulis dan studi dokumen sekolah pada semester genap tahun ajaran 2015/2016 di sekolah piloting kurikulum 2013, diperoleh gambaran bahwa sebagian besar guru mematuhi standarisasi terbatas pada dokumen, sedangkan implementasi di kelas masih memerlukan pengamatan dengan cermat agar yang diharapkan oleh standard proses pembelajaran dapat terpenuhi, dalam pengamatan tersebut masih ada sebagian guru di sekolah piloting SMA Negeri di Balikpapan, masih belum berubah dari pola pembelajarannya yang dikhawatirkan belum mengikuti sebagaimana kriteriakriteria yang ditetapkan standard proses pembelajaran.

Penelitian lain yang memperkuat implementasi standard proses menurut Salim (2015) dengan judul Implementasi Standar Proses dalam mata Pelajaran PAI di Kecamatan Sumowono Kabupaten Semarang, temuan penelitiannya dalam pelaksanaan pembelajaran pada tahap pendahuluan, penyiapan peserta didik secara fisik dan psikis, dan pelaksanaan apersepsi belum dilakukan, tujuan pembelajaran sudah dilakukan. Kelemahan lain dalam kegiatan inti guru mampu menggunakan media dan sumber belajar yang beragam, para guru belum melibatkan peserta didik secara aktif dalam pembelajarannya. Sedangkan dalam kegiatan penutup guru belum menyimpulkan jalannya pembelajaran.

Dalam aspek implementasi pembelajaran bermutu, memerlukan keterampilan menyiapkan pembelajaran dengan terencana, memahami aspek-aspek 
penyusunan persiapan pelaksanaan pembelajaran (RPP) dengan memedomani standard isi atau kurikulum dan memperhatikan standard kompetensi lulusan (SKL), yang dituangkan dalamnya RPP memerlukan penyiapan media, bahan ajar, skenario pembelajaran dan perangkat penilaian. Sebagai turunan dari silabus pembelajaran, karakteristik RPP bagi sekolah bahkan kelas tertentu tidak bisa disamakan dengan lainnya apalagi sekolah yang lain dengan performa siswa dan lingkungan yang karakteristik kultur sosial banyak perbedaannya, untuk itu kompetensi guru dituntut merencanakannya dengan sebaik-baiknya.

Sebagian besar guru masih sulit memahami karakteristik peserta didiknya, sehingga penyiapan indikator yang ditentukan untuk mencapai pembelajaran yang akan dilaksanakan menjadi kurang terang benderang, kondisi ini memerlukan peran semua pihak khususnya kecermatan pengurus MGMP dan pengembang kurikulum sekolah biasa lebih fokus dalam mengidentifikasi keluhan guru peserta MGMP, untuk mampu dipecahkan bersama dalam aktivitas terprogram.

Menurut Alimudin (2014) menyatakan ada beberapa kata kunci dalam penilaian autentik, yakni 1) Penilaian input, yakni menilai kemampuan awal siswa terkait apa yang akan dipelajari. Misalnya: pretest, apersepsi, brainstorming; 2) penilaian proses, yakni penilaian pada saat proses pembelajaran berlangsung. Misalnya menilai kesungguhan siswa, penerimaan siswa, kerjasama, kemampuan menyelesaikan tugas yang diberikan, penilaian diri, penilaian antar sejawat, dan lain-lain; 3) penilaian hasil, yakni menilai kompetensi siswa setelah proses pembelajaran berlangsung. Misalnya menilai kompetensi pengetahuan siswa dengan cara tertulis, lisan atau penugasan, dan menilai keterampilan siswa dengan cara tes praktik/unjuk kerja, portofolio, tugas proyek.

\section{METODE PENELITIAN}

Metode Penelitian ini adalah Kualitatif, pendekatan kolagial dengan pengawas Pembina pada masing-masing sekolah, nara sumber dipilah berdasarkan karakteristik tertentu yang ditetapkan pengawas sekolah dan kepala sekolah.

Proses pengumpulan data dengan observasi berupa pengamatan pembelajaran guru mata pelajaran atas kesepakatan pada masing-masing sekolah, wawancara kepada nara sumber seperti guru senior, siswa terbaik pada masing-masing sekolah, dan perwakilan orangtua peserta didik. Studi dokumentasi sekolah seperti KKM, daftar siswa tiap kelas.

Analisis data menggunakan program exel dari hasil pengamatan pembelajaran, input data wawancara dibuat transkrip, reduksi data dan trianggulasi. Hasil data baik hasil pengamatan dan hasil wawancara nara sumer dipilah kemudian disajikan dalam diskrepsi data.

\section{HASIL DAN PEMBAHASAN}

1. Diskripsi Umum SMA Piloting Kurikulum 2013

Pada temuan hasil penelitian ini diuraikan terlebih dahulu kondisi umum sebagai pengungkit keberlangsungan mutu proses pembelajaran di masingmasing sekolah. Alat pengungkit seperti Visi sekolah sebagai akar utama sekolah dalam mewujudkan cita-citanya bersama pihak berkepentingan tentang hal-hal yang akan dicapai. Untuk menjelaskan hal tersebut berikut disajikan visi untuk masing-masing sekolah sebagai obyek penelitian sebagai berikut: 
Tabel 4.1.1. Visi dan SMA Kategori Piloting Tahun 2016.

\begin{tabular}{|c|l|l|}
\hline No & Nama Sekolah & \\
\hline 1 & SMA Negeri 1 & $\begin{array}{l}\text { "Menghasilkan Insan Relegius, Berkarakter, Berprestasi, } \\
\text { Berwawasan Global dan Berbudaya Lingkungan". }\end{array}$ \\
\hline 2 & SMA Negeri 2 & $\begin{array}{l}\text { Terwujudnya Sekolah Yang Menghasilkan Insan Cerdas: } \\
\text { Berakhlak Mulia, Unggul Dalam Iptek Dan Berbudaya Bangsa }\end{array}$ \\
\hline 3. & SMA Negeri 5 & $\begin{array}{l}\text { Terwujudnya siswa/i yang berimtaq, BerIPTEKS, Berbudaya } \\
\text { Lingkungan, dan Berwawasan Nasional. }\end{array}$ \\
\hline
\end{tabular}

Sumber: Sekolah Piloting SMA Kota Balikpapan Tahun 2016.

Ketetapan visi sekolah tersebut di atas, sekolah menggunakan acuan sebagai langkah penetapan program-program yang dimuat dalam anggaran pendapatan dan belanja sekolah, dalam hal ini dikenal pula (APBS), tercermin dalam setiap detail program yang dilaksanakan dalam program tahunan sekolah, untuk ketiga sekolah ini mencantumkan beberapa program unggulan dalam mencapai standar proses pembelajaran tersaji di bawah ini.

Tabel 4.1.2. Program Yang Mendukung Implementasi Kurikulum 2013

\begin{tabular}{|c|c|c|}
\hline No. & Nama Sekolah & Visi Sekolah \\
\hline 1. & SMA Negeri 1 & $\begin{array}{l}\text { 1) Penyelenggaraan workshop untuk guru Informasi dan } \\
\text { Teknologi Computer(ICT). } \\
\text { 2) Penyelenggaraan workshop bagi Guru, Model-model } \\
\text { Pembelajaran. } \\
\text { 3) Penyelenggaraan workshop pembelajaran untuk abad 21, } \\
\text { pembelajaran berpusat pada siswa. }\end{array}$ \\
\hline 2. & SMA Negeri 2 & $\begin{array}{l}\text { 1) Penyusunan perangkat pembelajaran Kurikulum } 2013 \text { bagi guru } \\
\text { SMANegeri } 2 \text {. } \\
\text { 2) Penyusunan Modul system SKS oleh TIM guru. }\end{array}$ \\
\hline 3. & SMA Negeri 5 & $\begin{array}{l}\text { 1) Penyusunan Penilaian Sikap dalam Kurikulum } 2013 . \\
\text { 2) Pengintegrasian media Sosial untuk media pembelajaran siswa. }\end{array}$ \\
\hline
\end{tabular}

Sumber: Sekolah Piloting SMA Kota Balikpapan Tahun 2016

2. Diskripsi Perencanaan Pembelajaran

Perencanaan pembelajaran yang menghasilkan dokumen persiapan pembelajaran dilakukan oleh masing-masing guru mata pelajaran melalui mekanisme kerja kelompok dalam organisasi Musyawarah Guru Mata Pelajaran (MGMP) di tingkat sekolah, kemudian dibawa pada forum MGMP di tingkat Kota.
Hasil dokumen pembahasan di tingkat kota tersebut sepakat dijadikan sebagai alat pemandu pelaksanaan pembelajaran pada masing-masing sekolah piloting SMA. Untuk menyelaraskan persiapan guru dan peserta didik pada masing-masing sekolah ini kepada para peserta didik dihimbau mendownload materi yang akan dipelajari satu hari 
sebelum jadual pelajaran dilaksanakan.

Untuk tetap menjamin kebersamaan di antara peserta didik pada masingmasing sekolah, instruksi penyiapan materi pembelajaran dilaksanakan dengan membentuk kelompok. Berjalannya system ini pada masing-masing sekolah, karena masing-masing sekolah secara intensif berkomunikasi aktif dengan para orangtua, baik melalui mekanisme rapat orangtua dan sekolah maupun sekolah menginisiasi dengan membuat group media sosial pada masing-masing group kelas dengan administratornya wali kelas.
Dari persiapan administratif guru sebagaimana ditetapkan dalam surat edaran Dinas Pendidikan Kota Balikpapan, pada tiap awal semester tentang validasi perangkat pembelajaran, di sinilah semua guru dan MGMP menyikapi untuk pemenuhan administrasi persiapan pembelajaran pada masing-masing sekolah. Adapun bentuk administrasi persiapan guru dalam pembelajaran tergambar dalam capaian masing-masing sekolah di bawah ini bersumber dari Pengawas sebagai berikut:

Tabel 4.3.1. Hasil Skor (Jumlah, Rata-rata dan Prosentasi) Perencanaan Pembelajaran Guru SMANegeri 5

\begin{tabular}{|c|c|c|c|c|c|c|c|c|c|c|c|}
\hline $\begin{array}{l}\text { Unsur } \\
\text { Perencanaan }\end{array}$ & $\underset{\overrightarrow{0}}{\overrightarrow{0}}$ & $\begin{array}{l}\overrightarrow{0} \\
0 \\
0 \\
0 \\
0\end{array}$ & 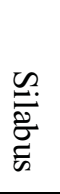 & 胥 & $\underset{\theta}{\overparen{\sigma}}$ & 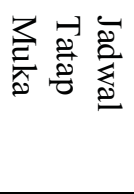 & 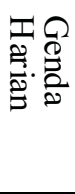 & Z. & 冥 & 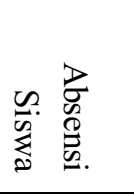 & $\begin{array}{l}\overrightarrow{0} \\
\stackrel{0}{\vec{D}}\end{array}$ \\
\hline Jumlah SKOR & 40 & 39 & 30 & 40 & 32 & 33 & 30 & 39 & 38 & 39 & 355 \\
\hline Rata-rata & 4,0 & $\overline{3,9}$ & 3,0 & 4,0 & 3,2 & 3.3 & 3.0 & 3.9 & 3.8 & 3,9 & 35,7 \\
\hline Prosentase & 100 & 97.5 & 80 & 100 & 80 & 82.5 & 80 & 97,5 & 95 & 97,5 & 81,25 \\
\hline
\end{tabular}

Untuk memperjelas maksud tabel di atas, hasil capaian persiapan guru mata pelajaran di SMA Negeri 5 tahun
2016/2017 semester ganjil di atas selanjutnya digambarkan pada sajian grafik sebagai berikut:

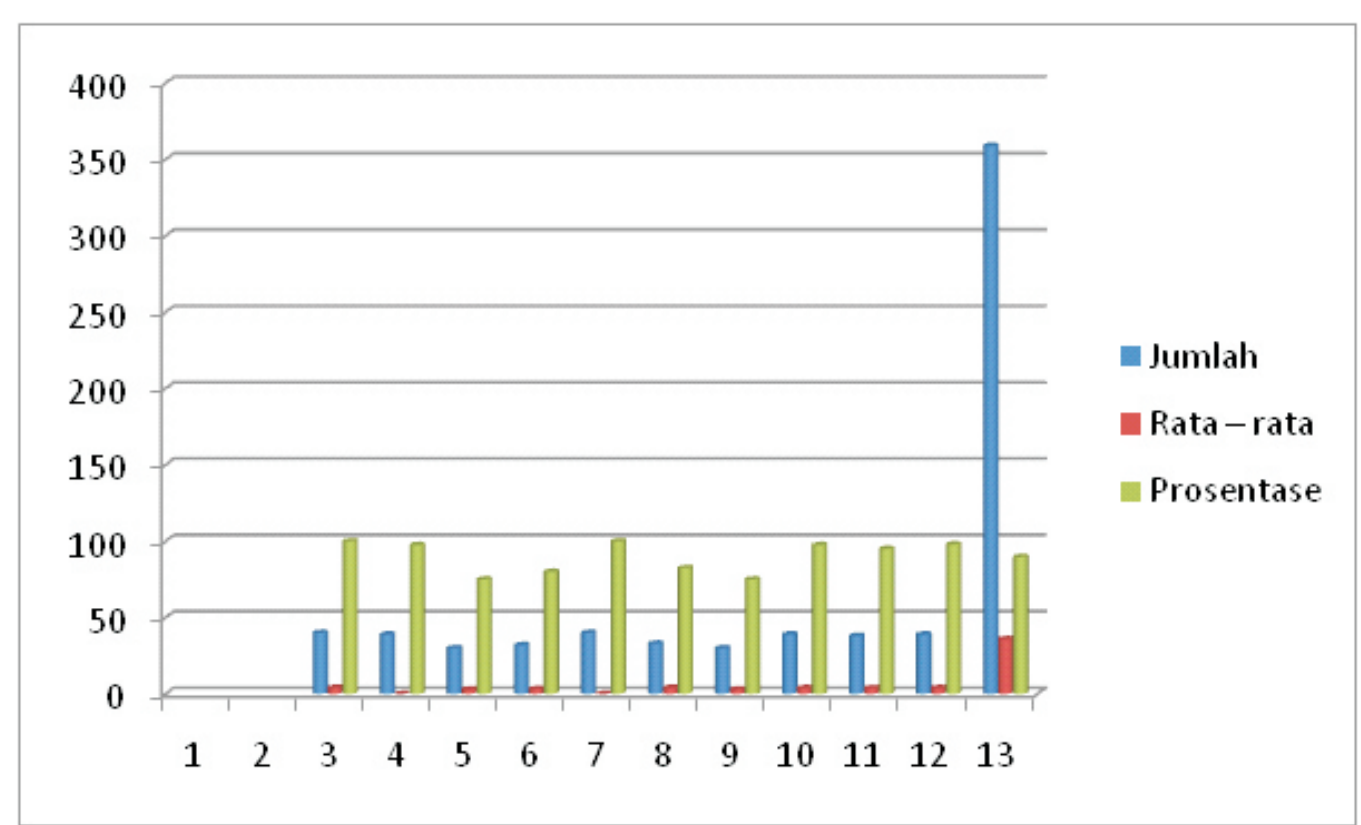

Gambar 4.3.1. Data Rata-rata Perolehan Hasil Perencanaan Guru SMA Negeri 5 Balikpapan Semester 1 Tahun 2016/2017 
Untuk menampilkan detail pada masing-masing sekolah tentang capaian perencanaan pembelajaran guru, di sekolah piloting SMA Negeri 2 Balikpapan menampilkan tabel sebagai berikut:

Tabel 4.3.2. Hasil Skor (Jumlah, Rata-rata dan Prosentasi) Perencanaan Pembelajaran Guru SMANegeri 2

\begin{tabular}{|c|c|c|c|c|c|c|c|c|c|c|c|}
\hline $\begin{array}{l}\text { Unsur } \\
\text { Perencanaan }\end{array}$ & $\underset{D}{20}$ & $\begin{array}{l}\text { ज्ञ } \\
0 \\
0 \\
\Xi \\
\Xi\end{array}$ & $\begin{array}{l}\mathscr{\mathscr { E }} \\
\stackrel{\tilde{\tilde{E}}}{\tilde{E}} \\
\end{array}$ & 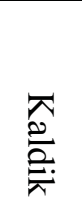 & $\underset{\nabla}{\nabla}$ & 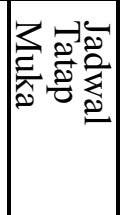 & 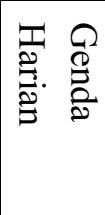 & 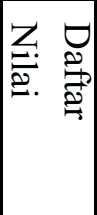 & 原 & 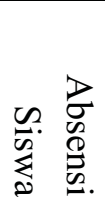 & 멀 \\
\hline Jumlah SKOR & 39 & 37 & 33 & 33 & 40 & 35 & 32 & 38 & 38 & 40 & 355 \\
\hline Rata-rata & 3,9 & 3,7 & 3,3 & 3,3 & 4,0 & 3.5 & 3.2 & 3.8 & 3.8 & 40 & 3,55 \\
\hline Prosentase & 97,5 & 92,5 & 82,5 & 82,5 & 100 & 87.5 & 80 & 95 & 95 & 40 & 85,25 \\
\hline
\end{tabular}

Dari tampilan tabel tersebut di atas agar memberikan gambaran lebih konkrit ditampilkan grafik berkaitan hal di atas dalam pemahaman pembaca berikut ini sebagai berikut:

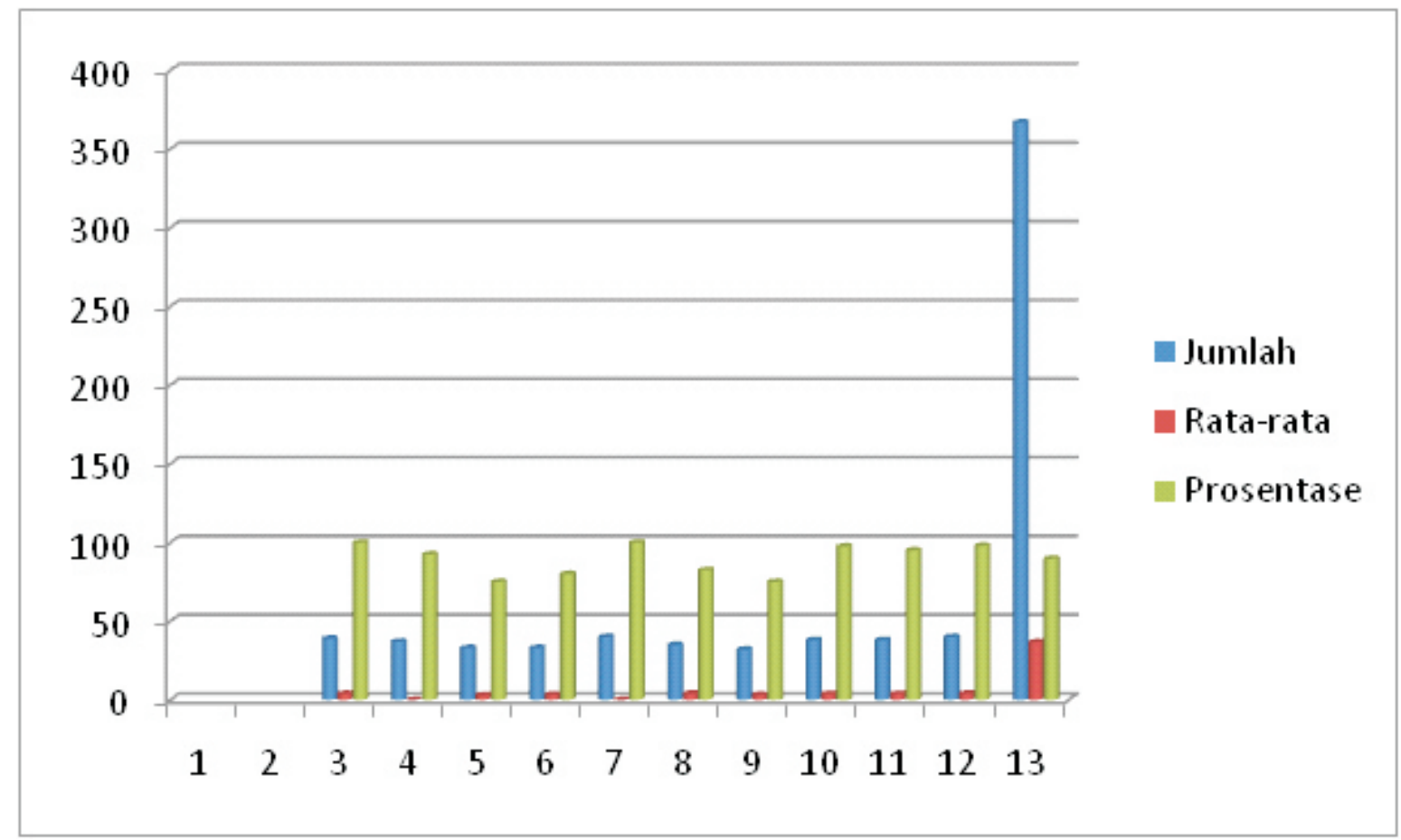

Gambar 4.3.2. Data Rata-rata Perolehan Hasil Perencanaan Guru SMA Negeri 2 Balikpapan Semester 1 Tahun 2016/2017

Deskripsi data dari perencanaan pembelajaran sekolah piloting di Balikpapan, berikut ini ditampilkan hasil capaian perencanaan pembelajaran guru mata pelajaran di SMA Negeri 1, tergambar pada tabel sebagai berikut: 
Tabel : 4.3.2. Hasil Skor (Jumlah, Rata-rata dan Prosentasi) Perencanaan Pembelajaran Guru SMANegeri 1

\begin{tabular}{|c|c|c|c|c|c|c|c|c|c|c|c|}
\hline $\begin{array}{l}\text { Unsur } \\
\text { Perencanaan }\end{array}$ & $\underset{0}{0}$ & $\begin{array}{l}\overrightarrow{0} \\
0 \\
0 \\
0 \\
B\end{array}$ & 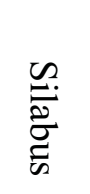 & 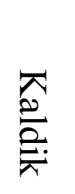 & Zृ &  & 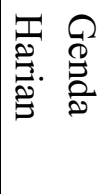 & 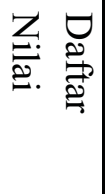 & 麦 & 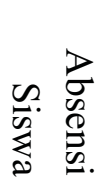 & $\stackrel{\overrightarrow{0}}{\stackrel{0}{D}}$ \\
\hline Jumlah SKOR & 40 & 37 & 37 & 40 & 39 & 35 & 39 & 38 & 38 & 38 & 381 \\
\hline Rata-rata & 4 & 3,9 & 3 & 4 & 3.9 & 3.5 & 3.9 & 3.8 & 3.8 & 3.8 & 3,91 \\
\hline Prosentase & 100 & 92.5 & 92.5 & 100 & 97.5 & 87.5 & 97.5 & 95 & 95 & 95 & 95,25 \\
\hline
\end{tabular}

SMA Negeri 1 sebagai sekolah utama yang menyelenggarakan Kurikulum 2013 terus berusaha menyesuaikan kondisi regulasi dan tuntutan masyarakat, salah satu upayanya adalah meningkatkan kompetensi pedagogik dalam pemahaman aspek dan prinsip-prinsip penyusunan RPP, maka terlihat capaian tersebut disajikan lebih lanjut dalam grafik sebagai berikut:

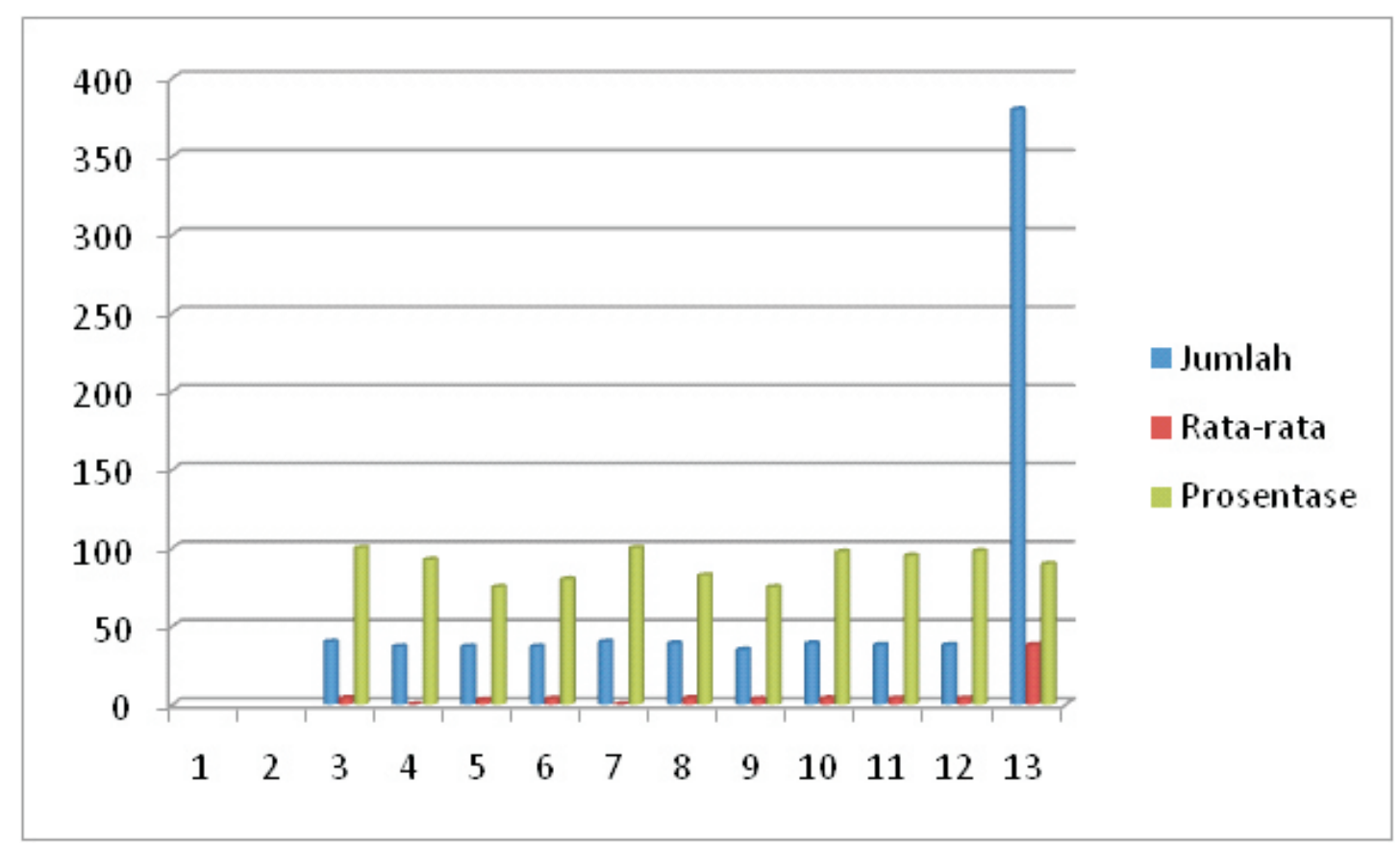

Gambar 4.3. Data Rata-rata Perolehan Hasil Perencanaan Guru SMA Negeri 1 Balikpapan Semester 1 Tahun 2016/2017

3. Diskripsi Hasil Capaian Standar Proses Pembelajaran

Dalam penyajian pelaksanaan pembelajaran data penelitian ini lebih menitik beratkan pada hasil wawancara. Pelaksanaan pembelajaran guru pada tiga sekolah piloting menggambarkan kaidahkaidah pembelajaran mencakup pengembangan ranah sikap, pengetahuan, dan keterampilan yang dielaborasi untuk setiap satuan pendidikan dalam mencapai sasarannya.

Berdasarkan Permendikbud nomor 22 tahun 2016 tentang standar proses untuk mencapai sasaran ketiga ranah afektif, pengetahuan, dan keterampilan tentu terjadi lintasan perolehan (proses psikologis) yang berbeda pada setiap peserta didik. Sikap diperoleh melalui aktivitas "menerima, menjalankan, meng- 
hargai, menghayati, dan mengamalkan". Pengetahuan diperoleh melalui aktivitas "mengingat, memahami, menerapkan, menganalisis, mengevaluasi, mencipta". Keterampilan diperoleh melalui aktivitas "mengamati, menanya, mencoba, menalar, menyaji, dan mencipta".

Dari aspek pelaksanaan pembelajaran kurikulum 2013 mengacu pada persyaratan antara lain; (1) Alokasi waktu selama 45 Menit sebagai satuan waktunya.
(2) rombongan belajar setiap kelas ditempati selama pembelajaran sebanyak 36 peserta didik, (3) ketersediaan buku teks pembelajaran, (4) pengelolaan kelas dan laboratorium untuk meneguhkan uraian di atas berikut sajian tabel hasil pengamatan pembelajaran, dimulai dari prasyarat pembelajaran dan penyelenggaraan kegiatan pembelajaran pada masing-masing sekolah dengan ringkasan sebagai berikut:

Tabel: 4.4.1. Hasil Pengamatan Komulatif Pelaksanaan Pembelajaran SMA Negeri 5 Semester Ganjil 2016/2017

\begin{tabular}{|c|c|c|c|c|c|c|c|c|c|c|c|}
\hline \multirow{2}{*}{$\begin{array}{c}\text { HASIL } \\
\text { PENGAMATAN } \\
\text { KOMULATIF }\end{array}$} & \multicolumn{4}{|c|}{$\begin{array}{c}\text { Indikator } \\
\text { Persyaratan } \\
\text { PEMBELAJARAN }\end{array}$} & \multirow[b]{2}{*}{ 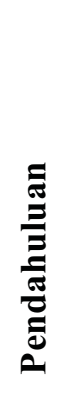 } & \multicolumn{3}{|c|}{ Keg. Inti Pembel } & \multirow[b]{2}{*}{ E } & \multirow[b]{2}{*}{ 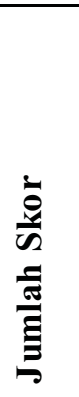 } & \multirow{2}{*}{ 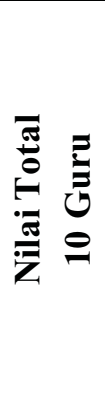 } \\
\hline & $\begin{array}{l}\frac{E}{\pi} \\
\frac{\pi}{\pi} \\
\frac{\pi}{\pi}\end{array}$ & 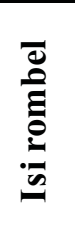 & 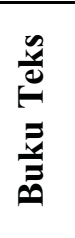 & 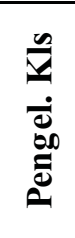 & & 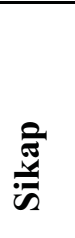 & 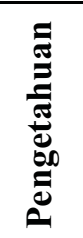 & 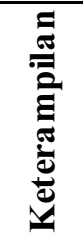 & & & \\
\hline Jumlah & 37 & 33 & 35 & 38 & 38 & 31 & 34 & 35 & 34 & 315 & 787,5 \\
\hline Rata-rata & 3,9 & 3,4 & 3,6 & 4,0 & 3,7 & 3,5 & 3,3 & 3,5 & 3,4 & & 78,75 \\
\hline Prosentase & 93 & 85 & 90 & 100 & 92.5 & 85 & 82.5 & 87.5 & 85 & & $\begin{array}{l}87,55 \\
\text { Persen }\end{array}$ \\
\hline
\end{tabular}

Selanjutnya untuk menggambarkan hasil pengamatan pembelajaran pada sekolah piloting kedua di Kota Balikpapan yakni
SMA Negeri 2 dipaparkan berikut ini sebagai berikut:

Tabel: 4.4.2. Hasil Pengamatan Komulatif Pelaksanaan Pembelajaran SMA Negeri 2 Semester Ganjil 2016/2017

\begin{tabular}{|c|c|c|c|c|c|c|c|c|c|c|c|}
\hline \multirow[b]{2}{*}{$\begin{array}{c}\text { HASIL } \\
\text { PENGAMATAN } \\
\text { KOMULATIF }\end{array}$} & \multicolumn{4}{|c|}{$\begin{array}{c}\text { Indikator Persyaratan } \\
\text { PEMBELAJARAN }\end{array}$} & \multirow[b]{2}{*}{ 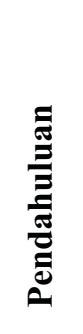 } & \multicolumn{3}{|c|}{ Keg. Inti Pembel } & \multirow[b]{2}{*}{ 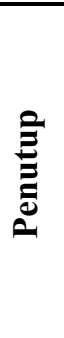 } & \multirow[b]{2}{*}{ 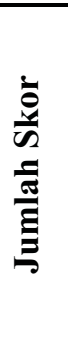 } & \multirow[b]{2}{*}{ 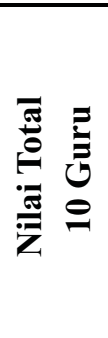 } \\
\hline & $\frac{E}{\frac{E}{\pi}}$ & $\begin{array}{l}\bar{\Xi} \\
\bar{E} \\
\overline{0} \\
0 \\
0\end{array}$ & $\begin{array}{l}\frac{n}{e} \\
\stackrel{0}{E} \\
\frac{E}{\bar{D}}\end{array}$ & 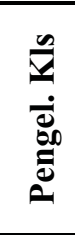 & & $\begin{array}{l}\frac{\hat{\pi}}{\bar{s}} \\
\frac{\bar{y}}{\bar{n}}\end{array}$ & 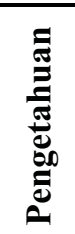 & 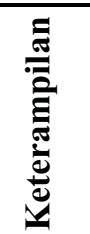 & & & \\
\hline Jumlah & 39 & 34 & 36 & 40 & 37 & 35 & 33 & 35 & 34 & 323 & 807,5 \\
\hline Rata-rata & 3,9 & 3,4 & 3,6 & 4,0 & 3,7 & 3,5 & 3,3 & 3,5 & 3,4 & & 80,75 \\
\hline Prosentase & 93 & 85 & 90 & 100 & 92.5 & 85 & 82.5 & 87.5 & 85 & & $\begin{array}{l}88.88 \\
\text { Persen }\end{array}$ \\
\hline
\end{tabular}


Kedua sekolah piloting tersebut di atas menurut sumber data di sekolah masing-masing, pada awalnya penyelenggaraan pembelajaran dengan kurikulum 2013, tentu ada kendala-kendala teknis, seperti prasarat tersedianya buku paket hampir semua sekolah terkendala hal ini. Yang dilakukan oleh sekolah seperti mendownload materi semua pelajaran yang tersedia di Kemendikbud, kemudian di copykan kepada guru dan para siswanya secara berkelompok.

Persoalan penilaian tiga ranah, afektif, pengetahuan dan psikomotorik, terjadinya penafsiran yang tajam di antara guru mata pelajaran dan para pengawas mata pelajaran, semua ini sebagai proses dan kemapanan system pendidikan pada satuan pendidikan, setelah terbitnya Permendikbud baru pada tahun 2014, kondisi mulai membaik karena adanya penyederhanaan system penilaian terutama sikap, karena akan berimplikasi pada penulisan laporan pendidikan pada setiap peserta didik.

Sekolah piloting yang cukup mapan, namun tetap menghadapi kendala adalah SMA Negeri 1, sebagai sekolah yang banyak kesempatan mengirimkan gurugurunya menjadi instruktur nasional (IN) sebutan pada saat itu, SMA Negeri 1 amat diuntungkan terutama dalam percepatan penerapan pembelajaran dan penilaian, sehingga sekolah ini cukup lebih gesit melaju dalam implementasi standar proses pembelajaran, untuk itu berikut disajikan tabel hasil pengamatan penulis dan pengawas Pembina di SMA 1 sebagai berikut:

Tabel: 4.4.3. Hasil Pengamatan Komulatif Pelaksanaan Pembelajaran SMA Negeri 1 Semester Ganjil 2016/2017

\begin{tabular}{|c|c|c|c|c|c|c|c|c|c|c|c|}
\hline \multirow[b]{2}{*}{$\begin{array}{c}\text { HASIL } \\
\text { PENGAMATAN } \\
\text { KOMULATIF }\end{array}$} & \multicolumn{4}{|c|}{$\begin{array}{c}\text { Indikator Persyaratan } \\
\text { PEMBELAJARAN }\end{array}$} & \multirow[b]{2}{*}{ 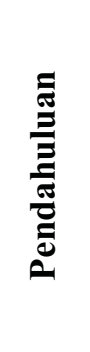 } & \multicolumn{3}{|c|}{ Keg. Inti Pembel } & \multirow[b]{2}{*}{ 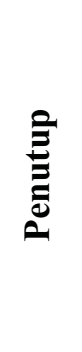 } & \multirow[b]{2}{*}{ 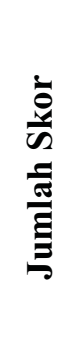 } & \multirow[b]{2}{*}{ 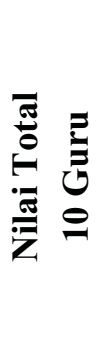 } \\
\hline & $\frac{E}{\frac{E}{\pi}}$ & $\begin{array}{l}\bar{d} \\
\bar{E} \\
0 \\
0 \\
0 \\
0\end{array}$ & 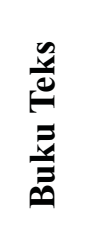 & 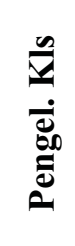 & & 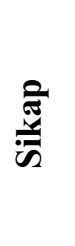 & 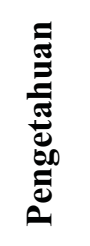 & 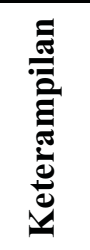 & & & \\
\hline Jumlah & 40 & 35 & 39 & 40 & 39 & 36 & 37 & 37 & 37 & 340 & 850 \\
\hline Rata-rata & 4,0 & 3,5 & 3,9 & 4,0 & 3,9 & 3,6 & 3,7 & 3,7 & 3,7 & & 8,5 \\
\hline Prosentase & 100 & 88 & 97,5 & 100 & 97,5 & 90 & 92,5 & 92,5 & 92,5 & & 94,44 \\
\hline
\end{tabular}

Dari tabel di atas, hasil akhir dari capaian pelaksanaan standar proses pembelajaran menunjukkan prosentasi 94\% dari sembilan (9) aspek yang dipersyaratkan dalam Permendikbud nomor 22 tahun 2014. Dengan kondisi ini
SMA Piloting sering disebut sekolah perintis penyelenggara kurikulum 2013 dapat digambarkan lebih sederhana perbandingan ketiga sekolah tersebut di atas sebagai berikut: 
Tabel 4.4.1 : Rekapitulasi Ketercapaian Pelaksanaan Standar Proses Pembelajaran SMA Piloting Tahun 2016 Kota Balikpapan

\begin{tabular}{|c|c|c|c|c|c|c|c|c|c|c|c|c|}
\hline \multirow[b]{2}{*}{$\mathrm{NO}$} & \multirow[b]{2}{*}{$\begin{array}{c}\text { NAMA } \\
\text { SEKOLAH }\end{array}$} & \multicolumn{4}{|c|}{$\begin{array}{c}\text { Indikator Persyaratan } \\
\text { PEMBELAJARAN }\end{array}$} & \multirow{2}{*}{ 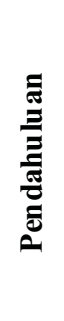 } & \multicolumn{3}{|c|}{ Keg. Inti Pembel } & \multirow[b]{2}{*}{ 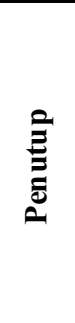 } & \multirow[b]{2}{*}{ 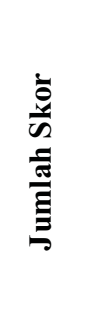 } & \multirow[b]{2}{*}{ 节 } \\
\hline & & 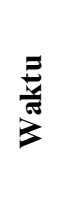 & 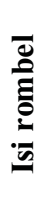 & 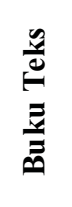 & 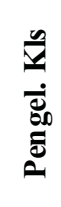 & & $\frac{\hat{A}}{\bar{i}}$ & 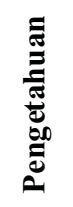 & 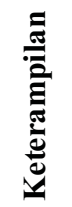 & & & \\
\hline 1 & SMA NEGERI 5 & 93 & 85 & 90 & 100 & 92.5 & 83 & 81.5 & 86 & 84 & 875.5 & 87,55 \\
\hline 2 & SMA NEGERI 2 & 93 & 85 & 90 & 100 & 92.5 & 85 & 82.5 & 87.5 & 85 & 888.8 & 88.88 \\
\hline 3 & SMA NEGERI 1 & 100 & 88 & 97,5 & 100 & 97,5 & 90 & 92,5 & 92,5 & 92,5 & 944.4 & 94,44 \\
\hline
\end{tabular}

Standar proses mengukur terlaksananya proses belajar peserta didik berdasarkan kriteria seperti waktu, waktu yang ditetapkan selama 45 menit, jika tiap guru tepat berada dalam kelas diikuti dengan kesiapan peserta didiknya untuk masing-masing sekolah secara kolektif, pada masing-masing sekolah ditemukan hanya di SMA Negeri 1 saja. Untuk kedua sekolah lainnya mendapatkan skor 93, karena tidak semua guru bisa mengelola waktu belajar tepat waktu, ada beragam ketidak tepatan itu, karena perlu waktu untuk bergeser dari kelas yang satu ke kelas yang lainnya. Perpindahan waktu dari mata pelajaran satu ke mata pelajaran lainnya, tempat ruang guru yang jauh dari kelas tempat belajar, belum lagi para siswa harus antri makan di kantin sekolah. Pada tiap mata pelajarannya untuk 10 guru yang diamati maka ditemukan total waktu 450 menit sebagai contoh ilustrasi.

Isi rombongan belajar tiap kelas, tiaptiap tahunnya sulit dipenuhi yakni 36 orang peserta didik tiap kelas. Kesulitan ini karena standar yang diajukan pemerintah pusat sulit dipenuhi atau ditaati oleh pihak sekolah, selama kurun waktu SMA di bawah otoritas pemerintah daerah, karena kuatnya intervensi kepentingan kolektif di tengah masyarakat, kondisi ini hanya sekolah yang pimpinan sekolahnya kuat saja yang mampu mendekati standar, semakin sekolah jumlahnya tiap rombel mendekati bahkan lebih dari 40 sulit mendapatkan angka 100 dari prasyarat ini. untuk ketercapaian Perspektif pembelajaran menurut para narasumber yang diwawancarai secara terstruktur atas persetujuan pihak sekolah, dinyatakan bahwa proses pembelajaran sebagaimana dilakukan oleh guru mata pelajaran di kelas diukur standar waktunya.

Buku teks mata pelajaran sekalipun sebagai standar harus tercukupinya setiap anak 1 buku, sekolah piloting masih juga sulit terpenuhi, tidak semua mata pelajaran bisa disediakan di perpustakaan, karena birokrasi dan pembiayaan pengadaan yang begitu rumit dan panjang, hingga pengiriman dari Jakarta pun harus diatur mekanismenya, hal ini tidak satu pun sekolah bisa memenuhi prasyarat ini. Akhirnya kondisi ini disikapi oleh masingmasing sekolah buku soft copy sebagai salah satu cara percepatan siswa dapat memperolehnya kemudian mereka mencetak sendiri, ada pula sekolah yang dengan rela hati menyediakan print out dari materi pelajaran yang akan dibahas untuk dicopy masingmasing peserta didiknya, siasat ini tidak seutuhnya berhasil karena siswa kadang- 
kadang kurang disiplin menanggapi kekurangan bahan ajar ini, ada siswa yang mengabaikan karena masalah ketersediaan buku ajar mudah didapat dengan fasilitas internet yang cukup di sekolah maupun di rumahnya, namun tidak semua siswa bisa menikmati hal ini jika dikembalikan dengan kondisi ekonomi orang tua di rumah masing-masing.

Pengelolaan kelas sebagai standar prasyarat penyelenggaraan pembelajaran di SMA/MA, SMK tidak hanya pengelolaan kelas konvensional hanya ada ruangan dan isinya, tetapi lebih kepada prasyarat keteladanan, masing-masing sekolah secara faktual selama penelitian di SMA Negeri 1, SMA Negeri 2 dan SMA Negeri 5 mampu dipenuhi. Hal ini dapat dipahami karena bisa jadi guru yang diajukan dalam pengamatan oleh sekolah merupakan guru pilihan, sehingga aspek pemenuhan kompetensi pedagogic, kepribadian dan sosial mampu ditepati selama proses pembelajaran itu berlangsung, hal ini diperkuat oleh penilaian lewat wawancara dengan peserta didik yang disepakati pihak sekolah benar adanya.

Memasuki kegiatan pembelajaran di kelas, data ini bersumber murni dari pengamatan peneliti dan data pengamatan oleh pengawas Pembina di masing-masing sekolah. Kegiatan pendahuluan mengacu pada kriteria yang diamanatkan oleh instrumen yang dikeluarkan Badan Standar Nasional Pendidikan. Angka 92,5 dari skala 100, merupakan angka yang diperoleh sekolah piloting kedua sekolah mendapatkan angka itu, sedangkan SMA 1 mendapatkan angka 97,5 dari skala 100, perhatian pada instrumen pengamatan pembelajaran setidaknya terdapat lima komponen, seperti, penyiapan pra pembelajaran, menyampaikan tujuan pembelajaran, memberikan motivasi, apersepsi, dan sistematika pembelajaran.

Kegiatan inti pembelajaran mengacu pada ketercapaian standar, integrasi pembelajaran yang menghasilkan pembentukan sikap dan pengetahuan serta keterampilan di sini integrasi sikap diperoleh skor 83-90 dari skala 100. Pengamatan tidak begitu sederhana karena komponen sikap begitu luas dan diamati setiap pembelajaran, angka penilaian sikap ini merupakan angka yang muncul dari pengawas yang telah diperoleh persetujuan guru yang diawasi.

Pengetahuan diperoleh dari angka 81,592,5 dari skala 100, menggambarkan bahwa kemampuan guru kedua sekolah seimbang dalam pelayanan membentuk pengetahuan peserta didiknya, sedangkan di SMA Negeri 1 diperoleh angka 97,5 hal ini dipengaruhi pula oleh motivasi internal masing-masing sekolah dari input masuk, dari aspek perolehan nilai ujian nasional dan pembobotan lainnya skala tertinggi didapat dari SMA Negeri 1 dan SMA Negeri 2 dan lima relative sebanding, demikian pula untuk pelayanan guru mata pelajaran yang diamati menghasilkan tampilan yang demikian adanya.

Angka perolehan skor 86-92,5 dalam skala 100, dari kedua sekolah mendapatkan angka 87,5 dalam membentuk keterampilan dalam pembelajaran, sedangkan SMA 1 mendapatkan angka 92,5 aspek yang membedakan adalah kinerja pengelolaan guru dalam praktik di laboratorium sekolah, semakin guru lebih banyak belajar di kelas biasa, karena berbagai alasan dan meninggalkan laboratorium sekolah, hal ini mempengaruhi skor ini, keaktifan penjaga dan pengelola laboratorium menjadi pemicu angka ini terwujud, karena pengelolaan kelas ternyata tidak sesederhana dalam pengetahuan orang awam hanya ada di kelas umumnya.

Penutup pembelajaran diperoleh angka 84-92,5 dalam skala 100, menggambarkan kegiatan penutup pembelajaran merupakan aktivitas guru dan murid yang setidaknya memiliki beberapa komponen seperti kegiatan merangkum pelajaran bersama guru dan peserta didik, memberikan umpan balik guru kepada peserta didik, menyampaikan 
penilaian selama pembelajaran, melakukan refleksi pembelajaran, dan menyampaikan garis besar rancangan pembelajaran berikutnya, menyampaikan penugasan dan materi yang akan dibahas berikutnya.

\section{PENUTUP}

\section{Simpulan}

Simpulan dari penelitian adalah prosentasi dari sekolah piloting SMA di Kota Balikpapan, telah memenuhi standar proses pembelajaran menurut Permendikbud nomor 22 tahun 2016, hal ini dibuktikan dengan ketercapaian hasil pengamatan pembelajaran 87,55, dan prosentasi ketercapaian sebesar 88.88 dalam skala 100 bagi SMA Negeri 5 Balikpapan, dan SMA Negeri 1 mendapatkan angka ketercapaian pemenuhan standar proses pembelajaran sebesar 94,44 persen dari skala 100. Perolehan-perolehan angka tersebut di atas jika dikategorikan dalam indikator yang ditetapkan pengawas Pembina masing-masing sekolah, yakni amat baik 90100, baik 80-89 dan 70-79 kategori cukup dan kategori kurang di bawah angka 70. Dengan kondisi itu ketercapaian standar proses pembelajaran di sekolah piloting menghasilkan amat baik dan baik. Untuk SMA Negeri 5 dan SMA Negeri 2, dan SMA Negeri 1 dengan kategori amat baik. Pengkategorian tersebut sudah pula dilakukan wawancara dari aspek pembelajaran dari beberapa nara sumber yang ditunjuk oleh sekolah.

\section{Saran}

Saran bagi peneliti berikutnya:

1. Keterbatasan penelitian ini adalah tidak mengamati perencanaan evaluasi pembelajaran dari aspek administrasinya maupun aspek produk penilaiannya, untuk itu sangat dimungkinkan peneliti berikutnya melakukan upaya yang mendalam mengangkat tema penilaian pelaksanaan kurikulum 2013 pada sekolah piloting.
2. Musyawarah guru mata pelajaran disingkat (MGMP) merupakan induk satusatunya organisasi kekaryaan guru, yang patut didorong melalui peran dan fungsinya dalam meningkatkan standarisasi pembelajaran pada sekolah masingmasing.

3. Peran orangtua dalam mengevaluasi dan memberikan masukan kepada guru dalam penyempurnaan implementasi standard proses pembelajaran pada masing-masing mata pelajaran.

\section{DAFTAR PUSTAKA}

Afriani Rika. 2014. Implementasi Standar Proses Mata Pelajaran Bahasa Indonesia di SMA Negeri 2 Balikpapan. Skripsi FKIP Universitas Balikpapan.

Alimudin. 2014. Penilaian dalam Kurikulum 2013. Prosiding Seminar Nasional. Universitas Negeri Makasar.

Hoy, C. Jardine, C.B. \& Wood, M. 2000. Improving Quality In Education. London; Falmer Press.

Kemendikbud. 2016. Peraturan Menteri Pendidikan dan Kebudayaan Republik Indonesia Nomor 22 Tahun 2016, tentang Standar Proses Pendidikan Dasar dan Menengah. Jakarta.

Sulistyo Bambang. 2013. Implementasi Pembelajaran Bahasa Indonesia Berdasarkan Kurikulum 2013. Prosiding ISBN 978-602-14802-0-5 Bandung, STKIP Siliwangi.

Salim. 2015. Implementasi Standar Proses Dalam Pembelajaran Pendidikan Agama Islam Pada SD Kecamatan Sumowono Kabupaten Semarang. Tesis. Pasca Sarjana. IAIN Salatiga. 